\title{
CORPORATE SOCIAL RESPONSIBILITY PADA INDUSTRI PERBANKAN SYARIAH DI INDONESIA
}

\author{
Ahmad Rizal Solihudin \\ Universitas Ahmad Dahlan \\ arsolihudin@gmail.com
}

\begin{abstract}
The paradigm of sustainability development developed by Bank Indonesia is in line with the principles used in corporate social responsibility (CSR). This study aims to map and analyze performance of CSR in Islamic banking industry in Indonesia. The methods of data collection using observation in annual reports with content analysis techniques. To analyze relationship between variables, in this study used data analysis tool with multiple linear regression analysis. The examine result proves that level of profitability of sharia banks significantly affect performance of CSR activities. While the size of the company and corporate governance proxied by the existence of independent commissioners did not give a significant effect on performance of Islamic banking CSR in Indonesia.
\end{abstract}

Keywords: corporate social responsibility, sharia banking

\section{PENDAHULUAN}

Bank Indonesia sebagai salah satu regulator industri perbankan di Indonesia menjadi pendorong utama program sustainability development di industri perbankan. Paradigma sustainability development yang dikembangkan Bank Indonesia bertumpu pada tiga pondasi utama yaitu profit, people dan planet. Dari tiga pondasi ini, Bank Indonesia mengeluarkan berbagai kebijakan untuk mengembangkan sustainability development di industi perbankan di Indonesia.

Secara garis besar paradigma profit, people dan planet yang dikembangkan Bank Indonesia sejalan dengan konsep corporate social responsibility (CSR). Konsep CSR memandu perusahaan untuk tidak hanya mempunyai tujuan mencari laba (profit) yang merupakan tujuan jangka pendek tetapi juga menjaga kepentingan jangka panjang dengan menerapkan tiga prinsip dasar yang dikenal dengan istilah triple bottom line yang terdiri dari profit, people, dan planet (Velasquez, 2012). Tiga prinsip tersebut menuntun perusahaan untuk turut serta mensejahterakan kehidupa sosial (people) serta menjamin kelangsungan hidup lingkungan (planet) untuk menjaga kepentingan jangka panjang. CSR bisa dianggap sebagai implementasi konkrit industri perbankan dalam usaha menjaga sustainability development perekonomian Indonesia.

CSR menjadi salah satu bentuk tanggung jawab perusahaan yang berkaitan dengan efek-efek yang terjadi akibat aktivitas 
operasional perusahaan. Semakin banyak bentuk pertanggungjawaban yang dilakukan, semakin meningkatkan image perusahaan pada stakeholder (Retno et al, 2012). Pendapat ini didasari sudah mulai perhatiannya pasar terhadap penerapan operasi perusahaan yang memperhatikan dampak terhadap kondisi sosial dan lingkungan. Hal inilah yang menumbuhkan kesadaran perusahaan bahwa pihak eksternal khususnya lingkungan dan masyarakat adalah bagian dari stakeholder yang harus dipenuhi kepentingannya (Marissa $e t$ al, 2013).

Perbankan syariah sebagai industri yang mengedepankan nilai-nilai ketuhanan tentu mempunyai kepentingan dengan isu sustainable development. Menghadapi tantangan dan persaingan industri perbankan yang semakin ketat, Bank Indonesia memprediksi bahwa CSR dapat menjadi competitive advantage industri perbankan syariah di masa depan. Hal ini bisa menjadi peluang bagi bank syariah sebagai titik unggul dalam persaingan di masa depan.

Isu berikutnya yang muncul adalah seberapa jauh aktifitas CSR bank syariah memberi dampak positif terhadap seluruh stakeholder secara proporsional. Secara teknis, belum ada peraturan yang jelas menjelaskan ketentuanketentuan aktifitas CSR bank syariah. Kebijakan aktifitas CSR secara umum masih diserahkan kepada masing-masing perusahaan. Hal ini tentu saja menyulitkan dalam hal pemerataan manfaat dari aktifitas CSR itu sendiri. Oleh sebab itu, penelitian berkaitan dengan CSR perlu dilakukan untuk memetakan kondisi CSR pada industri perbankan syariah.

\section{REVIEW LITERATUR DAN HIPOTESIS}

World Business Council mendefinisikan CSR sebagai komitmen bisnis secara berkelanjutan untuk ikut berkontribusi dalam pembangunan ekonomi, meningkatkan kualitas hidup pekerja dan keluarganya dan juga pada komunitas lokal dan masyarakat pada umumnya (Marzuki, 2011). Sedangkan Brigham dan Houston (2010) mendefinisikan CSR sebagai suatu konsep yang menyatakan bahwa perusahaan harus secara aktif turut serta memperhatikan kebutuhan kesejahteraan masyarakat secara luas.

Teori yang dapat digunakan sebagai landasan penerapan CSR adalah teori stakeholder. Elemen-elemen kewajiban sosial perusahaan yang berkembang merujuk pada teori stakeholder yang menyangkut isu sosial dalam kajian manajemen dan akuntansi (Sarvaes dan Tamayo, 2013). Teori stakeholder menjelaskan bahwa perusahaan sebagai suatu entitas individu dapat memberi pengaruh dan dipengaruhi oleh berbagai pihak yang disebut stakeholder.

Velasquez (2012) menjelaskan konsep CSR memandu perusahaan untuk tidak hanya mempunyai tujuan mencari laba (profit) yang merupakan tujuan jangka pendek tetapi juga menjaga kepentingan jangka panjang dengan menerapkan tiga prinsip dasar yang dikenal dengan istilah triple bottom line (profit, people, dan planet). Tiga prinsip tersebut menuntun perusahaan untuk turut serta mensejahterakan sosial (people) dan menjamin kelangsungan hidup (planet). Elkington (1997) dalam Emilson (2012) memberi pandangan bahwa perusahaan yang mempunyai orientasi jangka panjang menyangkut kelangsungan hidupnya haruslah memperhatikan "3P". Selain mengejar profit, perusahaan juga harus ikut serta dalam pemenuhan kebutuhan kesejahteraan masyarakat (people) dan kelestarian lingkungan (planet).

\section{Global Reporting Initiative (GRI)} merupakan sebuah kerangka laporan yang lazim dan diterima untuk mengkombinasikan laporan kinerja keuangan, lingkungan, dan sosial ke dalam satu format yang sama. Konsep pelaporan CSR yang digagas oleh GRI adalah konsep sustainability report yang muncul sebagai aplikasi pengembangan sustainability development. 
Sustainability report menggunakan skema triple bottom line yang tidak hanya melaporan kinerja yang diukur dari sudut pandang ekonomi saja, melainkan juga dari sudut pandang sosial dan lingkungan (Marzuki, 2011).

GRI Guidelines menyebutkan bahwa perusahaan harus menjelaskan dampak aktivitas perusahaan di dalam laporan tahunannya dalam 6 dimensi yaitu economic, environment, labor, human right, social, dan product. Masing-masing dimensi memiliki indikator yang digunakan sebagai alat ukur kinerja CSR yang dilaporkan perusahaan di laporan tahunan. Dalam penelitian ini digunakan tiga dimensi yaitu economic disclousure, environment disclousure dan social disclousure sebagai proksi kinerja perusahaan dalam penerapan konsep triple bottom line.

\section{Ukuran Perusahaan}

Penelitian Barnas dan Hapsari (2016) membuktikan bahwa ukuran perusahaan berpengaruh signifikan posifit terhadap kinerja CSR perusahaan. Hal ini menunjukkan bahwa besar kecilnya ukuran perusahaan berpengaruh terhadap aktifitas CSR. Pendapat ini didukung penelitian Purba dan Yadnya (2015) yang menguji pengaruh ukuran perusahaan dan profitabilitas terhadap kinerja CSR. Hasilnya menunjukkan ukuran perusahaan berpengaruh signifikan posiitf terhadap kinerja CSR.

\section{Profitabilitas (ROE)}

Penelitian Hermawan dan Mulyawan (2014) membuktikan bahwa tingkat profitabilitas perusahaan berpengaruh signifikan posifit terhadap kinerja CSR perusahaan. Hal ini menunjukkan bahwa semakin besar keuntungan suatu perusahaan berdampak pada semakin baiknya kinerja CSR. Pendapat ini didukung Kiran dan Shaheen (2015) yang meneliti pengaruh profitabilitas perusahaan di Pakistan terhadap kinerja CSR. Hasilnya menunjukkan tingkat keuntungan perusahaan berpengaruh signifikan terhadap kinerja CSR.

\section{Komposisi Dewan Komisaris}

Komisaris independen dalam dewan komisaris dijadikan mekanisme penerapan good corporategovernancepadaperusahaan.Komisaris independen diharapkan tidak mempunyai potensi konflik kepentingan sehingga proses pengawasan manajemen berjalan dengan efektif dan efisien. Penelitian Susilo dan Mildawati (2015) membuktikan bahwa praktik good corporate governance perusahaan berpengaruh signifikan posifit terhadap kinerja CSR perusahaan. Pendapat ini didukung penelitian Ramdhaningsih dan Utama (2013) yang menguji pengaruh good corporate governance terhadap luasan kinerja CSR. Hasilnya menunjukkan good corporate governance berpengaruh signifikan posiitf terhadap kinerja CSR. Berdasarkan pembahasan diatas, dikembangkan sembilan hipotesis sebagai berikut.

$\mathrm{H}_{1}$ : Tingkat keuntungan berpengaruh terhadap economic disclousure

$\mathrm{H}_{2}$ : Ukuran perusahaan berpengaruh terhadap economic disclousure

$\mathrm{H}_{3}$ : Komposisi dewan komisaris berpengaruh terhadap economic disclousure

$\mathrm{H}_{4}$ : Tingkat keuntungan berpengaruh terhadap environment disclousure

$\mathrm{H}_{5}$ : Ukuran perusahaan berpengaruh terhadap environment disclousure

$\mathrm{H}_{6}$ : Komposisi dewan komisaris berpengaruh terhadap environment disclousure

$\mathrm{H}_{7}$ : Tingkat keuntungan berpengaruh terhadap social disclousure

$\mathrm{H}_{8}$ : Ukuran perusahaan berpengaruh terhadap social disclousure 
$\mathrm{H}_{9}$ : Komposisi dewan komisaris berpengaruh terhadap social disclousure

\section{METODE PENELITIAN}

Penelitian ini termasuk penelitian explanatory dengan menggunakan pendekatan kuantitatif. Data yang digunakan dalam penelitian ini bertipe data panel diambil dari tahun 2013 sampai tahun 2016. Penelitian ini menggunakan data sekunder berupalaporan pertanggungjawaban manajemen perusahaan yang dilaporkan setiap tahunnya. Populasi dalam penelitian ini adalah seluruh bank syariah di Indonesia. Teknik pengambilan sampel menggunakan purposive sampling. Pemilihan sampel ini didasarkan pada pertimbangan kelengkapan laporan tahunan bank syariah terutama berkaitan dengan aktifitas CSR.

Instrumen yang dianalisis didasarkan pada ketentuan penerapan CSR yang ditetapkan Global Reporting Initiative (GRI). Data diperoleh dari laporan tahunan, literatur, artikel, dan sumber informasi lain yang berkaitan dengan subyek penelitian. Teknik pengumpulan data menggunakan content analysis. Teknik ini dilakukan dengan observasi terhadap laporan tahunan perusahaan dan catatan yang ada dalam sumber data yang digunakan. Pengujian hipotesis menggunakan analisis regresi berganda untuk mengetahui hubungan antara variabel independen dan dependen. Terdapat tiga model regresi yang digunakan untuk menguji hipotesis sebagai berikut.

Economic disclousure ${ }_{t}=\beta_{0}+\beta_{1} \mathrm{IND}_{\mathrm{it}}+\beta_{2} \mathrm{SIZE}_{\mathrm{it}}$ $+\beta_{3} \mathrm{ROE}_{\mathrm{it}}+\varepsilon_{\mathrm{t}}$

Environment disclousure ${ }_{t}=\beta_{0}+\beta_{1} \mathrm{IND}_{\mathrm{it}}+\beta_{2}$ $\mathrm{SIZE}_{\mathrm{it}}+\beta_{3} \mathrm{ROE}_{\mathrm{it}}+\varepsilon_{\mathrm{t}}$

Social disclousure $=\beta_{0}+\beta_{1} \mathrm{IND}_{\mathrm{it}}+\beta_{2} \mathrm{SIZE}_{\mathrm{it}}+\beta_{3}$ $\mathrm{ROE}_{\mathrm{it}}+\varepsilon_{\mathrm{t}}$
Keterangan:

$\begin{array}{ll}\text { IND } & \text { : Komposisi dewan komisaris } \\ \text { SIZE } & \text { : Ukuran Perusahaan }(\ln ) \\ \text { ROE } & : \text { Return on Equity }\end{array}$

Dalam penelitian ini, corporate social responsibility diproksikan dengan tiga variabel dengan penjelasan sebagai berikut:

\section{Economic Disclousure}

Laporan perusahaan berkaitan dengan nilai ekonomi yang dihasilkan dan didistribusikan secara langsung, meliputi pendapatan, biaya operator, kompensasi kepada karyawan, donasi dan investasi ke komunitas, laba ditahan dan pembayaran kepada investor dan pemerintah (pajak). Selain itu, penjelasan atas dampak ekonomi secara tidak langsung termasuk luasan dampak terhadap internal maupun eksternal perusahaan. Instrumen yang digunakan untuk mengukur economic disclousure sebanyak sembilan item. Pengukuran dilakukan dengan menggunakan pendekatan dikotomi, yaitu setiap item diberi nilai 1 jika diungkapkan, dan nilai 0 jika tidak diungkapkan. Rumus perhitungan pengukurannya sebagai berikut:

Economic Index ${ }_{\mathrm{j}}=\frac{\sum X_{\mathrm{y}}}{\mathrm{n}_{\mathrm{j}}}$

Keterangan:

$\mathrm{n}_{\mathrm{j}} \quad$ : jumlah item untuk perusahaan $\mathrm{j}, \mathrm{nj}=9$

$\mathrm{X}_{\mathrm{ij}}: 1=$ jika item $\mathrm{i}$ diungkapkan; $0=$ jika item $\mathrm{i}$ tidak diungkapkan

\section{Environment Disclousure}

Laporan perusahaan berkaitan dengan penggunaan sumber daya seperti energi. Selain itu laporan berkaitan dengan dampak operasi perusahaan terhadap lingkungan termasuk strategi, aktivitas saat ini dan rencana masa depan untuk mengelola dampak terhadap lingkungan. 
Instrumen yang digunakan untuk mengukur environment disclousure sebanyak 30 item. Rumus perhitungan pengukurannya sebagai berikut:

$$
\text { Environment Index }_{\mathrm{j}}=\frac{\sum X_{\mathrm{g}}}{\mathrm{n}_{\mathrm{j}}}
$$

Keterangan:

$\mathrm{n}_{\mathrm{j}} \quad$ : jumlah item untuk perusahaan $\mathrm{j}, \mathrm{nj}=30$

$\mathrm{X}_{\mathrm{ij}} \quad: 1=\mathrm{jika}$ item $\mathrm{i}$ diungkapkan; $0=\mathrm{jika}$ item i tidak diungkapkan

\section{Social Disclousure}

Laporan perusahaan berkaitan dengan sifat, cakupan, dan keefektifan atas program dan kegiatan apapun yang menilai dan mengelola dampak operasi terhadap masyarakat, termasuk saat memasuki wilayah operasi,selama beroperasi dan pasca operasi. Instrumen yang digunakan untuk mengukur Social disclousure sebanyak 7 item. Rumus perhitungan pengukurannya sebagai berikut:

Keterangan:

$$
\text { Social Index }_{\mathrm{j}}=\frac{\sum X_{\mathrm{y}}}{\mathrm{n}_{\mathrm{j}}}
$$

$\mathrm{n}_{\mathrm{j}} \quad$ : jumlah item untuk perusahaan $\mathrm{j}, \mathrm{nj}=7$

$\mathrm{X}_{\mathrm{ij}} \quad: 1=$ jika item $\mathrm{i}$ diungkapkan; $0=$ jika item i tidak diungkapkan

Pengujian terhadap hipotesis dilakukan dengan menguji koefisien regresi dari model yang digunakan. Pengujian hipotesis menggunakan uji statistik t. Menurut Ghozali (2005) uji statistik t pada dasarnya menunjukkan seberapa jauh pengaruh satu variabel independen secara individual dalam menerangkan variabel dependen.

\section{HASIL PENELITIAN DAN PEMBAHASAN}

Perhitungan regresi linier berganda digunakan untuk menganalisis pengaruh ROE, komposisi komisaris independen dan ukuran perusahaan terhadap kinerja CSR. Sebelumnya, tabel 1 menjelaskan analisis deskriptif dari variabel yang diamati dalam penelitian ini.

\section{Tabel 1}

\section{Hasil Perhitungan Statistik Deskriptif}

\begin{tabular}{|l|c|c|c|c|c|c|}
\hline & $\begin{array}{c}\text { Economic } \\
\text { disclousure }\end{array}$ & $\begin{array}{c}\text { Environment } \\
\text { disclousure }\end{array}$ & $\begin{array}{c}\text { Social } \\
\text { disclousure }\end{array}$ & $\begin{array}{c}\text { Komposisi } \\
\text { Komisaris }\end{array}$ & $\begin{array}{c}\text { Ukuran } \\
\text { Perusahaan } \\
(\ln )\end{array}$ & ROE \\
\hline Mean & 0.500 & 0.345 & 0.472 & 0.417 & 1.301 & 0.222 \\
\hline Max & 0.750 & 0.600 & 1.000 & 0.600 & 1.502 & 0.350 \\
\hline Min & 0.250 & 0.000 & 0.000 & 0.300 & 1.098 & 0.106 \\
\hline St Dev & 0.088 & 0.168 & 0.250 & 0.084 & 0.075 & 0.072 \\
\hline
\end{tabular}

Sumber: Hasil Pengolahan Data

Total unit analisis dalam penelitian ini sebanyak 34 laporan tahunan bank syariah tahun 2013 sampai 2016. Laporan tahunan tersebut dikeluarkan oleh 11 bank syariah di Indonesia. Nilai rata-rata economic disclousure sebesar 0,5 (nilai maksimal satu) menunjukkan $50 \%$ item pelaporan economic disclousure disampaikan rata-rata bank syariah. Nilai ratarata environment disclousure sebesar 0,345 (nilai maksimal satu) menunjukkan 34,5\% dari 30 item pelaporan environment disclousure disampaikan rata-rata bank syariah. Nilai standar deviasi social disclousure sebesar 0,25 menunjukkan simpangan antar bank syariah berkaitan dengan pelaporan social disclousure tinggi. Dari hasil perhitungan statistik deskriptif, dapat dikatakan bahwa tingkat pengungkapan CSR masih rendah (dibawah 50\%). Hal ini dapat dimungkinkan terjadi karena perbedaan model pelaporan CSR dengan ketentuan yang ditetapkan oleh GRI. 
Rata-rata jumlah komisaris independen bank syariah di Indonesia sebanyak 1 sampai 3 orang. Bank syariah dengan aset besar relatif memiliki jumlah komisaris independen lebih banyak dari yang lebih kecil.

Tabel 2 menunjukkan hasil regresi linier yang digunakan untuk menguji Sembilan hipotesis. Dari hasil perhitungan pada model economic disclousure dihasilkan $\mathrm{R}^{2}$ sebesar $16,1 \%$, environment disclousure dihasilkan $\mathrm{R}^{2}$ sebesar $22,8 \%$, sedangkan pada model social disclousure dihasilkan $\mathrm{R}^{2}$ sebesar $21,6 \%$. Pada tabel 2 ditunjukkan pengaruh ROE signifikan pada tingkat kepercayaan $10 \%$ terhadap economic disclousure dengan arah positif dan nilai signifikansi 1,8723 $\left(\mathrm{H}_{1}\right)$. Selain ROE, dua variabel independen lain yaitu ukuran perusahaan $\left(\mathrm{H}_{2}\right)$ dan komisaris independen $\left(\mathrm{H}_{3}\right)$ tidak signifikan mempengaruhi economic disclousure dengan nilai signifikansi masing-masing 0,746 dan $-1,4133$.

Hasil perhitungan yang ditunjukkan dalam tabel 2 pengaruh ROE signifikan pada tingkat kepercayaan 5\% terhadap environment disclousure dengan arah positif dan nilai signifikansi 2,4275 $\left(\mathrm{H}_{4}\right)$. Selain ROE, dua variabel independen lain yaitu ukuran perusahaan $\left(\mathrm{H}_{5}\right)$ dan komisaris independen $\left(\mathrm{H}_{6}\right)$ tidak signifikan mempengaruhi environment disclousure dengan nilai signifikansi masing-masing 0,7016 dan -1,5893. Pada model ketiga, pengaruh ROE signifikan pada tingkat kepercayaan 5\% terhadap social disclousure dengan arah positif dan nilai signifikansi 2,6078 $\left(\mathrm{H}_{7}\right)$. Selain ROE, dua variabel independen lain yaitu ukuran perusahaan $\left(\mathrm{H}_{8}\right)$ dan komisaris independen $\left(\mathrm{H}_{9}\right)$ tidak signifikan mempengaruhi environment disclousure dengan nilai signifikansi masing-masing 0,5852 dan $-1,0245$.
Tabel 2

Hasil Regresi

\begin{tabular}{|c|l|c|c|}
\hline Hipotesis & \multicolumn{1}{|c|}{ Variabel } & Koefisien & t-Statistic \\
\hline & Economic Disclousure & & \\
\hline $\mathrm{H}_{1}$ & ROE & 0.3981 & $1.8723 * *$ \\
\hline $\mathrm{H}_{2}$ & SIZE & 0.0095 & 0.7464 \\
\hline $\mathrm{H}_{3}$ & $\mathrm{IND}$ & -0.2887 & -1.4133 \\
\hline & $\mathrm{R}^{2}$ & & $16.1 \%$ \\
\hline & Environment Disclousure & & \\
\hline $\mathrm{H}_{4}$ & ROE & 0.9389 & $2.4275^{*}$ \\
\hline $\mathrm{H}_{5}$ & SIZE & 0.0162 & 0.7016 \\
\hline $\mathrm{H}_{6}$ & IND & -0.5905 & -1.5893 \\
\hline & $\mathrm{R}^{2}$ & & $22.8 \%$ \\
\hline & Social Disclousure & & \\
\hline $\mathrm{H}_{7}$ & ROE & 1.5108 & $2.6078^{*}$ \\
\hline $\mathrm{H}_{8}$ & SIZE & 0.0202 & 0.5852 \\
\hline $\mathrm{H}_{9}$ & IND & -0.5701 & -1.0245 \\
\hline & $\mathrm{R}^{2}$ & & $21.6 \%$ \\
\hline
\end{tabular}

Sumber: Hasil Pengolahan data

* Signifikan pada level 5\%

**Signifikan pada level 10\%

Hasil pengujian membuktikan bahwa mayoritas hipotesis tidak terdukung. Pengujian hipotesis satu (H1) membuktikan bahwa tingkat keuntungan bank syariah signifikan mempengaruhi kinerja CSR pada aspek ekonomi. Hal ini mengindikasikan semakin besar keuntungan bank syariah, semakin besar aktifitas CSR berkaitan dengan aspek ekonomi. Hasil pengujian hipotesis dua (H2) membuktikan bahwa ukuran perusahaan tidak signifikan mempengaruhi kinerja CSR pada aspek ekonomi. Ukuran bank syariah tidak bisa menjadi tolak ukur aktifitas CSR berkaitan dengan aspek ekonomi. Begitu pula keberadaan komisaris independen tidak memberi pengaruh signifikan terhadap aktifitas CSR di bidang ekonomi.

Pengujian pada hipotesis empat (H4) membuktikan bahwa tingkat keuntungan bank 
syariah signifikan mempengaruhi kinerja CSR pada aspek lingkungan. Hal ini mengindikasikan semakin besar keuntungan bank syariah, semakin besar aktifitas CSR berkaitan dengan aspek lingkungan. Hasil pengujian hipotesis dua (H2) dan hipotesis tiga (H3) membuktikan bahwa ukuran perusahaan dan corporate governance yang diproksikan komposisi dewan komisaris tidak signifikan mempengaruhi kinerja CSR pada aspek ekonomi. Kinerja CSR bidang lingkungan bank syariah tidak dipengaruhi secara signifikan oleh ukuran bank dan corporate governance.

$$
\text { Pengujian hipotesis tujuh }
$$
membuktikan bahwa tingkat keuntungan bank syariah signifikan mempengaruhi kinerja CSR pada aspek kemasyarakatan. Hal ini mengindikasikan semakin besar keuntungan bank syariah, semakin besar aktifitas CSR berkaitan dengan bidang kemasyarakatan. Hasil pengujian membuktikan bahwa hipotesis delapan (H8) dan hipotesis Sembilan (H9) tidak terdukung. Hasil pengujian hipotesis delapan (H8) membuktikan bahwa ukuran perusahaan tidak signifikan mempengaruhi kinerja CSR pada aspek masyarakat. Ukuran bank syariah tidak bisa menjadi tolak ukur aktifitas CSR berkaitan dengan aspek kemasyarakatan. Begitu pula hasil pengujian hipotesis Sembilan (H9) membuktikan keberadaan komisaris independen tidak memberi pengaruh signifikan terhadap aktifitas CSR di bidang kemasyarakatan.

Teori stakeholder menjelaskan bahwa setiap entitas perusahaan mempunyai kewajiban sosial dalam bisnisnya. Kewajiban itu adalah menggunakan seluruh sumber daya untuk menghasilkan profit yang sejalan dengan kepentingan stakeholder (Beltratti, 2005). Apabila dikembalikan pada konsep yang mendasarinya, corporate social responsibility tidak ada kaitannya dengan penyisihan laba. Konsep triple bottom line tidak menuntut perusahaan untuk melakukan aktifitas-aktifitas diluar aktifitas operasi perusahaan. Sebaliknya, konsep CSR berusaha mengoptimalkan tujaun dari setiap aktifitas operasi perusahaan termasuk bank syariah tidak hanya berorientasi laba tetapi juga people, dan planet (Velasquez, 2012). Pada dasarnya penerapan CSR mengharuskan perusahaan menjadi sebuah entitas bisnis yang tidak hanya memfokuskan semua operasinya untuk keuntungan finansial tetapi juga memperhatikan tujuan sosial dan lingkungan.

Penelitian Retno (2012) menunjukkan semakin banyak bentuk pertanggungjawaban yang dilakukan perusahaan terhadap semakin meningkatkan image perusahaan. Hal ini tentu penting bagi bank syariah bahwa pihak eksternal (lingkungan dan masyarakat) adalah bagian dari stakeholder yang harus dipenuhi kepentingannya oleh perusahaan untuk menjaga keberlangsungannya (Fiore, 2014). Selain itu, sebagai sebuah korporasi, bank syariah dianggap mempunyai sumber daya yang seharusnya bisa dibagi kepada kepentingan masyarakat dan sosial. Bagi bank syariah sendiri, CSR menjadi salah satu tumpuan mempertahankan eksistensinya. (Velasquez, 2012).

\section{KESIMPULAN DAN SARAN}

\section{Kesimpulan}

Berdasarkan hasil analisis dan pembahasan dapat disimpulkan beberapa hal sebagai berikut: (1) Variabel ROE signifikan mempegaruhi kinerja aktifitas CSR pada aspek ekonomi, lingkungan dan kemasyarakatan. (2) Ukuran perusahaan tidak signifikan mempengaruhi kinerja CSR pada bank syariah di Indonesia. (3) Penerapan corporate governance yang diproksikan dengan keberadaan komisaris indepeden tidak memberi pengaruh signifikan terhadap kinerja CSR bank syariah di Indonesia.

\section{Saran}


Corporate Social Responsibility Pada Industri Perbankan Syariah di Indonesia

Peneliti berikutnya disarankan menggunakan alat ukur lain dalam mengukur kinerja corporate social responsibility (seperti Proper). Selain karena CSDI sangat tergantung kecermatan peneliti dalam menganalisis, penggunaan alat ukut lain akan lebih memperkuat teori yang ada. Selain itu, penggunaan periode amatan terkini akan lebih dapat menggambarkan perkembangan tren corporatesocial responsibility di Indonesia.

\section{DAFTAR PUSTAKA}

Arthur J. Keown,et.all. 2005. Financial Management: Principles and Applications. New Jersey: Pearson.

Barnas, N. et al. 2016. Pengaruh Profitabilitas dan Ukuran Perusahaan terhadap Pengungkapan CSR. Vol.3(2). eProceeding of Management.

Beltratti, A. 2005. The complementarity between corporate governance and corporate social responsibility. Vol. 30(3). The Geneva Papers on Risk and InsuranceIssues and Practice.

Brigham, F. E., dan Houston, F. J. 2010. Essentials of Financial Management. Singapore: Cengage Learning Asia.

Cooper, D. R. dan Schindler, P. S. 2014. Business Research Methods, Twelfth Edition. Singapore: McGraw-Hill.

Emilsson, L. et al. 2012. CSR and the quest for profitability-using EVA. Vol. 2(3). International Journal of Economics and Management Sciences.
Hemawan, S. dan Mulyawan, G. 2014.Profitability and CSR. Vol. 3(1). Asia pacific Journal of Accounting and Finance.

Kiran, S. et al. 2015. CSR and Firm Profitaability. Vol. 5(1). City University Research Journal.

Marissa, Y. et al. 2013. Pengaruh CSR Terhadap Kinerja Keuangan Sektor Manufaktur. Vol. 2(1). Jurnal Mahasiswa Universitas Surabaya.

Marzuki, M. 2011. Hubungan Simultan CSR dan Kinerja Keuangan pada Perusahaan di BEI. Magister Manajemen UGM.

Purba, W. dan Yadnya, P. 2015. Pengaruh Ukuran Perusahaan dan Leverage terhadap Profitabilitas dan Pengungkapan CSR. Vol. 4(8). Ejurnal Manajemen Unud.

Ramdhaningsih, A dan Utama, K. 2013. Pengaruh Indikator GCG dan Profitabilitas pada Pengungkapan CSR. Vol. 3(3). E-Journal Akuntansi Universitas Udayana.

Retno, M. et al. 2012. Pengaruh GCG dan pengungkapan CSR Terhadap Nilai Perusahaan. Vol. 1(1). Jurnal Nominal.

Subramanyam, R.K dan Wild, John J. 2010. Analisis Laporan Keuangan:Financial Statement Analysis Buku 1-10/E. Jakarta : Salemba Empat.

Sarvaes, H dan Tamayo, A. 2013. The Impact of CSR on Firm Value. Vol. 59(5). Management Science Informs.

Susilo, S. Dan Mildawati, T. 2015. Pengaruh GCG terhadap Pengungkapan CSR. Vol. 4(5). Jurnal Ilmu \& Riset Akuntansi.

Velasques, M. 2012. Business Ethics. New Jersey: Peasson. 